Available Online at https://journal.unismuh.ac.id/index.php/otoritas

Otoritas : Jurnal Ilmu Pemerintahan, 11 (1), April 2021, 1-18

\title{
Unfreezing without Refreezing Change Management: Dilemmatic Roles of Agents in Succeeding the Bureaucracy Reform
}

\author{
Eko Prasojo ${ }^{1 *)}$, Miranda Putri1 ${ }^{1}$ Desy Hariyati ${ }^{1}$ \\ ${ }^{1}$ Department of Public Administration, Faculty of Administrative Science, Universitas Indonesia, \\ Depok, 16424, Indonesia
}

Received: 4 January 2021; Revised: 1 March 2021; Accepted: 27 April 2021

\begin{abstract}
The implementation of bureaucracy reform in many countries continues to experience various problems, in relation to the system, regulations and actors. The success of such reform shows the important role of the actors involved in promoting change agendas. Studies on bureaucracy reform have covered many aspects of the system, stages and factors that influence its success or failure. This study specifically analyses the aspect of the related actors, namely the role of change agents in the implementation of change management, who support the implementation of bureaucracy reform. Departing from theory regarding the role of agent of change and the stages of change management during the process of bureaucracy reform, the data collection was conducted through in-depth interviews with a number of stakeholders of National Development Planning Agency, Indonesia. The qualitative data is processed using the Discourse Network Analyzer. The results show that there are three roles conducted by the agent of change in pushing reform agendas, namely as catalysts, solution givers and as process helper. To improve the performance of their roles, there are at least two attributes that they must have, i.e., skills and behavioral attributes, which both play a significant role in supporting the success of bureaucracy reform.
\end{abstract}

Keywords: Agent of Change; Indonesia; Change Management; Administrative Reform; Bureaucracy Reform

How to Cite: Prasojo, E., Putri, M., \& Hariyati, D. (2021). Unfreezing without Refreezing Change Management: Dilemmatic Roles of Agents in Succeeding the Bureaucracy Reform. Otoritas : Jurnal Ilmu Pemerintahan, 11(1), 1-18.

Permalink/DOI: https://doi.org/10.26618/ojip.v11i1.4694

${ }^{*}$ Corresponding Author.

E-Mail : prasojo1@ui.ac.id

Copyright (C) 2021, Otoritas : Jurnal Ilmu Pemerintahan, ISSN: 2088-3706 (Print), ISSN: 2502-9320 (Online) 
Available Online at https://journal.unismuh.ac.id/index.php/otoritas

Otoritas : Jurnal Ilmu Pemerintahan, 11 (1), April 2021, 2

\section{INTRODUCTION}

The process of bureaucracy reform in Indonesia has experienced ups and downs since the introduction of the concept in an effort to improve the government system, which is considered by the community to be poor. One of the reasons for its inadequate implementation was the lack of suitable and regular patterns, so in 2010 the Road Map for Bureaucracy Reform was drawn up as a basis for the process. One of the important aspects of implementing bureaucracy reform is the need for agents of change to be formed, as parties who are expected to be able to promote the movement. Agents of change face a major challenge in encouraging bureaucracy reform because of the culture of abuse of authority and the justification of behavior that does not follow the code of ethics and values of government agencies (Saiffudin, 2020). Based on this, agents of change are responsible for influencing the way of thinking and working culture of the apparatus of government agencies so that they are in line with the goals of bureaucracy reform. Moreover, the presence of change agents also aims to support the implementation of change, either by facilitating, initiating, implementing or directing it (Gerwing, 2016).

The implementation of government in Indonesia cannot be separated from various problems and irregularities that affect the performance of its bureaucracy, meaning that the services provided to the public are of poor quality. Various bureaucratic irregularities, often termed as bureaucratic pathologies, frequently occur in the Indonesian government. One of these that commonly takes place is maladministration, which is an act or behavior that violates the law, the use of authority for personal interests, or neglect of obligations in performing public services which causes harm to service recipients, materially or immaterially (Nurtjahjo, Hendra Maturbongs \&
Rachmitasari, 2013).

Based on the results of data collection from a number of reports of suspected maladministration in public services conducted by the Ombudsman of the Republic of Indonesia, in the period 20112017 there were at least 10,558 reports of complaints received from all over the country (Ombudsman Republik Indonesia, 2018). Considering the periods 2012 2013 and 2015-2016, there were a sharp increases of 2,964 and 2,171 cases respectively. In terms of the various categories of public complaint related to maladministration, the three ranked most highly were protracted delays, with 2,351 reports, procedural irregularities, with 1,799 reports, and lack of provision of services, with 1,403 reports (Ombudsman Republik Indonesia, 2018). These three highest categories represent the inadequacy of state civil apparatus in carrying out its obligations to provide a better, cheaper and faster service.

In light of the various irregularities that take place in the bureaucracy of Indonesia, the government has implemented remedial efforts through bureaucracy reform of all government agencies, both central and regional. It decided to implement such reform to create an accountable and professional government system by implementing holistic change efforts in a structured, integrated and comprehensive manner in all elements of bureaucracy, including institutions, human resources, accountability, supervision and public services (Yusriadi, 2018). The implementation of bureaucracy reform was mandated by the President of the Republic of Indonesia in Presidential Regulation of the Republic of Indonesia Number 81 of 2010 concerning the Grand Design of $\mathrm{Bu}-$ reaucracy reform for 2010 - 2025, as a basis for the state to create good governance. It is hoped that bureaucracy reform will be able to restore and increase public trust in the government.

Realizing the sustainable implemen- 
tation of bureaucracy reform requires leadership commitment, a change in mindset, and a change in the work culture of the members to improve integrity and performance. To support the implementation of these changes, change pioneers were needed who could be an example for every member of work units to follow organizational values. Therefore, the Ministry of PAN RB issued a Regulation of the Minister of Administrative Reform and Bureaucracy reform Number 27 of 2014 concerning Guidelines for Development of Change Agents in Government Agencies. The formation of agents of change in each government agency aims to improve the integrity of organizational members and improve performance and professionalism so that irregularities can be avoided (Kementerian Pendayagunaan Aparatur Negara dan Reformasi Birokrasi, 2014). In addition, change agents are shown to be role models for the behavior for the organization, working to promote changes so that these can be implemented in the smallest work unit (Kementerian Pendayagunaan Aparatur Negara dan Reformasi Birokrasi, 2014).

Gerwing (2016) reveals that change agents are an important component in the change process because they initiate, facilitate, implement and support organizational change. In the implementation of bureaucracy reform in Indonesia, agents of change face enormous challenges due to the culture of abuse of authority and of the justification of behavior that does not follow the code of ethics and values of government agencies (Saiffudin, 2020). This negative culture needs to be changed in order to create members with high integrity and performance; therefore, agents of change were created with duties and functions regulated by the Regulation of the Minister of Administrative Reform and Bureaucracy reform Number 27 of 2014. First, agents of change are catalysts, tasked with convincing all members of the importance of change. Second, as change drivers, their role is to motivate organizational members to participate in the change. Third, as solution providers, change agents have the responsibility to provide input to members or leaders in the work environment. Fourth, they serve as mediators, in charge of assisting the change process, especially in terms of problem-solving. Finally, they act as liaison officers, in charge of promoting communication between members and leaders.

Similar to Gerwing's argument, Moran dan Brightman (2000) argue that change management is a process that is applied to create a continuous renewal of the direction, structure and ability to provide services to both internal and external organizations. Therefore, in implementing such management, a process, tools and techniques are needed to manage human resources in realizing change (Baker, 2007). In the development of the implementation of change management, there is a related model that is often applied in organizations, namely the change management model of Lewin (1951), which consists of three stages: unfreeze, move and refreeze.

Lewins (1951) argues that to implement change in an organization, the first important step is to dilute the existing atmosphere (status quo) to a neutral situation, a stage which is known as unfreezing (Hossan, 2015), which will provide an improvement in the behavior of organizational members. This driving force for change will minimise any resistance that may arise (Hussain et al., 2016). Lewins (1951) explains that this dimension comprises three activities, namely identifying the factors that drive change (driving forces); the forces driving resistance to change (resisting forces); and providing information related to differences in existing and expected behavior (psychological disconfirmation) (Cummings \& Worley, 2005).

Lewins (1951) states that the activi- 
ties performed in the moving stage are the process of implementing change with the involvement of various stakeholders. At this stage, there is a shift in the behavior of organizations, departments and individuals by utilising the system to develop behaviors, values and attitudes through the development of new skills and competencies (Worley \& Mohrman, 2014). The final stage proposed by Lewins (1951) is refreezing, which is performed to create stability for the changes that have been made by utilising support mechanisms to strengthen the state of the organization (Rosenbaum et al., 2018). Four activities are performed: providing change resources; building a support system for change agents; developing competence and behavior; and continuing the steps to achieve the goals.

The Ministry of National Development Planning, or the National Development Planning Agency (Bappenas), is one of the government agencies which is implementing bureaucracy reform. The issuance of Presidential Regulation Number 65 of 2015 concerning the Ministry of National Development Planning is one of the reasons why bureaucracy reform at Bappenas needs to be implemented. To accelerate the process, Bappenas has created a change agency, which was established in 2010 and reformed in 2017. One of the tasks performed by change agents is to internalize change from a management perspective down to the smallest organizational unit, namely individuals. This is done so that changes made within Bappenas can be integrated and also implemented up to the work unit. During the last few years, change agents have performed various activities, such as the preparation of performance management guidelines, strategic SOPs for the preparation of the Government Work Plan (RKP) and the Ministry/Institution Work Plan (Renja K/L), and various other activities also aimed at strengthening the role of the Ministry of National Development Plan-
ning/Bappenas after the issuance of PP 17 of 2017 concerning Synchronization of the National Development Planning and Budgeting Process (SP4N).

Although several studies have already been done regarding bureaucracy reform in Indonesia, most of them focused on the implementation of the reform program, identification of key drivers and problems of successful reform, or the aspect of leadership as an important part of reform. Only few of them focused on the actors behind the process of reform and how their roles bring impact to the success or fail of reform. By focusing on this aspect, this article provides a comprehensive explanation of the roles and skills of agent of change that are contributed to the successful implementation of reform. Furthermore, this study provides a detail discussion by analyzing the change agent's roles in each step of reform, namely unfreeze, move, and refreeze. Hence, the results are not only contributed to the academic sphere, but also to practical realm for government, professional, and academia who are in charge in conducting bureaucracy reform.

Many developed countries have made use of advances in digital technology in combating corruption and improving their governance systems (Baktybayev, 2020; Dyussenov, 2019). Because with the implementation of this digital innovation solution facilitates services, cuts bureaucracy, while preventing and reducing extortion and corruption practices, but there are still problems that will arise in its application in Indonesia to be applied successfully (Suherry, 2017), especially in other regions that are not yet advanced in cities. big cities with the strength of their human resources and expertise in mastering the technology. This is evident in the fact that occurred in 2018, the success of the Corruption Eradication Commission (Komisi Pemberantasan Korupsi) of 30 Hand-catch Operation (highest achievement), 256 people were 
named as suspects of corruption, and among them 26 people were regional heads.

In the digital era like today, in the 2018 Global Digital Report, it is mentioned that internet users in Indonesia reached 132 million people or around $50 \%$ of the population, with an average internet usage duration of 8 hours 51 minutes per person every day (Buhalis et al., 2019). This indirectly changed the way the government communicates with the people to change very quickly. With the use of digital innovation multi-step communication models with a variety of channeled digital disruption in government also has a positive impact to improve the quality of public services (Supardal, 2016). This is due to the application of digital technology so that the process of public and government services becomes easier, faster and cheaper. Including better effectiveness in terms of control and supervision.

From the point of life that moves dynamically, the life of administrative ethics is expected to move in accordance with the times (Songklin, 2017). In the current situation, namely in the era of disruption or millennial era, ethical change has shifted and experienced many changes. The current condition of the crisis in Indonesia is felt because of the change in values and norms that should guide someone in the form of a habit that reflects a person's good and bad behavior. In this era of disruption, it is thought to be greatly influenced by technological developments that are increasingly developing. However, in its development this technology has positive and negative impacts. So the purpose of this research is to uncover the ethics of public administration in the era of government innovation disruption.

\section{RESEARCH METHODS}

A post-positivist approach was used, a process whereby researchers collect data that support, argue or make improve- ments to the theory that has been developed before conducting additional testing of it (Creswell, 2014). This research used illustrative method as data analysis techniques, utilizing existing theories to analyze the organizational situation concretely by making the National Development Planning Agency the research locus. To support the data analysis technique, the Discourse Network Analyzer (DNA) and Visione applications were employed to process the primary data. The data collection was conducted through in-depth interviews with nine sources, consisting of the person in charge of the change management area; change agent supervisor; four change agents; two representatives of the apparatus in the work unit; and a representative of one of the directors at Bappenas. The interviews were conducted by asking questions that had been compiled through concept operationalization mapping. To support the analysis, the researchers conducted literature study derived from theoretical studies, references and scientific literature related to culture, values and norms that apply to the social situation under study (Sugiyono, 2012).

\section{RESULTS AND DISCUSSION}

The Importance of Change Agent Existence

The implementation of change management within an organization needs to be supported by the individuals within it. To integrate change, organizations often appoint change agents, namely individuals or groups of individuals who have the responsibility to lead the changes and who can act to force change and provide motivation for other members to make changes (Klerk, 2010). Cawsey et al., (2012) argue that change agents are among the most important actors in the overall change process, who are the party tasked with making the diagnosis from the initial stage to the actual change im- 
Available Online at https://journal.unismuh.ac.id/index.php/otoritas

Otoritas : Jurnal Ilmu Pemerintahan, 11 (1), April 2021, 6

plementation process. This is because change agents initiate, facilitate, implement and support organizational change from start to finish (Gerwing, 2016). (Ottaway, 1983) describes the role of change agents as proposed by Havelock, (1973), following the three stages of change proposed by Lewins (1951), as shown in Figure 1.

The first role that the change agent must play is as a catalyst. Havelock (1973) argues that this involves motivating organizational members to support and implement the change process (Oliver, 2018). Therefore, Saka (2003) argues that agents of change should be people who have enthusiasm for change and will be active in influencing other members in their work unit (Klerk, 2010). Change agents also need to play the role of solution provider to other work unit members and to their superiors. Havelock (1973) explains that in the change process there will be various ideas related to change, but it is the change agents who must provide solutions effectively. Gilley (2001) states that change agents need to provide creative solutions based on the results of an analysis of existing conditions and to monitor the solutions proposed (Gerwing, 2016).

According to Havelock (1973), in the process of implementing change, change agents need to be the party that helps the change process in terms of being process helpers (Oliver, 2018 ). Change agents also play the role of helping the change process through problem-solving and by making innovations. They should be skilled at solving problems and be able to help parties such as members of the organization who are finding it difficult to make the changes. According to Havelock, the final role that change agents must play is as resource linkers Tupper $F$. Cawsey (2016). This liaison role is intended to unite people, and to assist members of the organization in finding and utilising resources that can be used both inside and outside the system.

To become an effective change agent in bringing about organizational change, several qualifications need to be fulfilled. To support the role, Weiss (2003) states that the first qualification is physical ability, namely the ability to utilise one's strength to achieve something. Weiss also argues that the skills of change agents are very important for the effective implementation of change. One of these is knowledge; Gilley (2005) argues that change agents need knowledge related to the change process to understand its complexities, and other knowledge to align the organization with its long-term direction, vision, mission and goals (Gerwing,

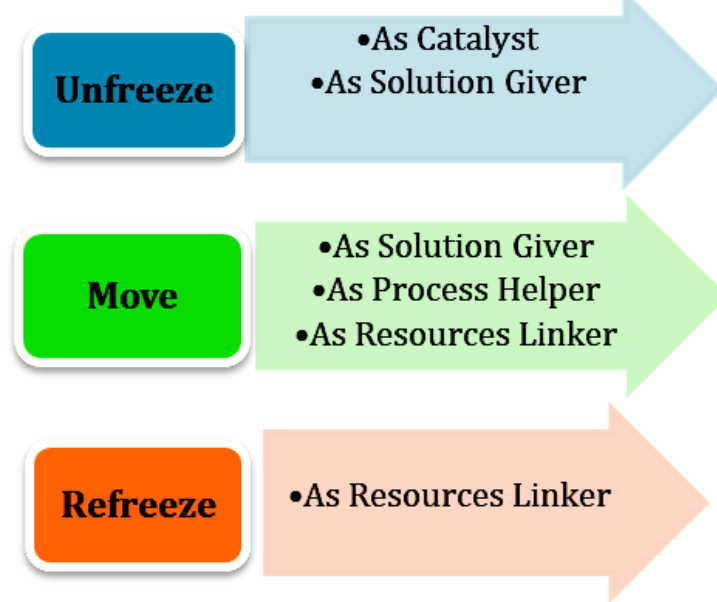

Figure 1. The Position of Change Agents Source: Ottaway (1983) 
Available Online at https://journal.unismuh.ac.id/index.php/otoritas

Otoritas : Jurnal Ilmu Pemerintahan, 11 (1), April 2021, 7

Table 1. Roles of Agent of Change

Source: Processed Data by the Authors (2020)

\begin{tabular}{|c|c|c|c|}
\hline Dimensions & Indicators & Sub-indicators & References \\
\hline \multirow[t]{5}{*}{ Unfreeze } & Driving factors for change & $\begin{array}{l}\text { The role of change agents in } \\
\text { identifying the drivers of } \\
\text { change }\end{array}$ & \multirow{3}{*}{$\begin{array}{c}\text { Lewins } \\
(1951), \\
\text { Hossan } \\
\text { (2015), } \\
\text { Hussain et } \\
\text { al. (2016), } \\
\text { Oliver } \\
\text { (2018), Sa- } \\
\text { ka (2003) }\end{array}$} \\
\hline & $\begin{array}{l}\text { The driving force of re- } \\
\text { sistance to change } \\
\text { (Resisting forces) }\end{array}$ & $\begin{array}{l}\text { The role of change agents in } \\
\text { identifying resistance and } \\
\text { suppressing resistance }\end{array}$ & \\
\hline & $\begin{array}{lr}\text { Identification } & \text { current and } \\
\text { expected } & \text { behaviors } \\
\text { (Psychological } & \text { disconfir- } \\
\text { mation) } & \\
\end{array}$ & $\begin{array}{l}\text { The role of change agents in } \\
\text { identifying current and ex- } \\
\text { pected organizational mem- } \\
\text { bers' behavior }\end{array}$ & \\
\hline & $\begin{array}{l}\text { Roles change agent as Cata- } \\
\text { lyst }\end{array}$ & $\begin{array}{l}\text { The way change agents } \\
\text { drive change within the or- } \\
\text { ganization }\end{array}$ & \multirow{2}{*}{$\begin{array}{c}\text { HHavelock } \\
\text { (1973), Gil- } \\
\text { ley (2001), } \\
\text { (Gerwing, } \\
2016), \\
\text { Klerk } \\
(2010)\end{array}$} \\
\hline & $\begin{array}{l}\text { Roles change agent as Solu- } \\
\text { tion Giver }\end{array}$ & $\begin{array}{l}\text { The involvement of change } \\
\text { agents in providing input } \\
\text { and decision making }\end{array}$ & \\
\hline \multirow[t]{4}{*}{ Move } & $\begin{array}{l}\text { The involvement of various } \\
\text { parties or stakeholders }\end{array}$ & $\begin{array}{l}\text { The ability of change agents } \\
\text { to involve members of the } \\
\text { organization in the change } \\
\text { process }\end{array}$ & $\begin{array}{c}\text { Lewins } \\
(1951), \\
\text { Worley \& } \\
\text { Mohrman } \\
(2014) \\
\end{array}$ \\
\hline & $\begin{array}{l}\text { Roles change agent as Pro- } \\
\text { cess Helper }\end{array}$ & $\begin{array}{l}\text { The way change agents can } \\
\text { help work units implement } \\
\text { change }\end{array}$ & \multirow{3}{*}{$\begin{array}{c}\text { Havelock } \\
\text { (1973), Oli- } \\
\text { ver (2018), } \\
\text { Cawsey et } \\
\text { al., (2016) }\end{array}$} \\
\hline & $\begin{array}{l}\text { Roles change agent as Solu- } \\
\text { tion Giver }\end{array}$ & $\begin{array}{l}\text { The involvement of change } \\
\text { agents in providing solu- } \\
\text { tions to problems in imple- } \\
\text { menting change }\end{array}$ & \\
\hline & $\begin{array}{l}\text { Roles change agent as Re- } \\
\text { sources Linker }\end{array}$ & $\begin{array}{l}\text { Involvement of change } \\
\text { agents as intermediaries for } \\
\text { top-level management and } \\
\text { the work unit }\end{array}$ & \\
\hline \multirow[t]{2}{*}{ Refreeze } & $\begin{array}{l}\text { Efforts to create stability in } \\
\text { organizational change. }\end{array}$ & $\begin{array}{l}\text { The change agent's efforts to } \\
\text { maintain the changes that } \\
\text { have been made }\end{array}$ & $\begin{array}{c}\text { Lewins } \\
\text { (1951), } \\
\text { Rosenbaum } \\
\text { at al. } \\
\text { (2018) }\end{array}$ \\
\hline & $\begin{array}{l}\text { Roles change agent as Re- } \\
\text { sources Linker }\end{array}$ & $\begin{array}{l}\text { The involvement of change } \\
\text { agents communicates the } \\
\text { determination of change }\end{array}$ & $\begin{array}{c}\text { Havelock } \\
\text { (1973), } \\
\text { Cawsey et } \\
\text { al., (2016) } \\
\end{array}$ \\
\hline
\end{tabular}


2016). Moreover, such knowledge is also seen in terms of the experience of the change agent, and the ability to frame problems (framing skills); diagnose problems (diagnostic participative skills); and solve problems (conflict resolution skills). They should also be good communicators. According to Weiss (2003), the final attribute that change agents need is related to behavior, including diligent behavior, risk-taking behavior, and creativity and innovation.

The researcher used the Discourse Network Analyzer, which was transformed to the application of Visione for the data output, to produce the three images shown in Figure 2, which represent the research results in the threedimensional stages related to change management.

The lines in each image connect the opinions of each source on each indicator in the dimensions of the change management stages. Three colors represent the answers of each interviewee for each indicator: green represents agreement with each indicator; red represents disagreement with the indicator; and blue represents answers that are considered contradictions. The three images show the results of the in-depth interviews on each dimension of the change management stages, namely unfreeze, move and refreeze.

As shown in Figure 2, the results of the data processing using the DNA illustrate the opinions of the participants and are divided into 24 green lines, two red lines and three blue lines. For the second indicator, all the informants agreed that change agents played a role in identifying and suppressing resistance, which is indicated by the unbroken green line connecting the resource person to indicator 2 . Meanwhile, for the other indicators, there are red and blue lines, even though they are all dominated by green lines, so it can be said that most informants agreed with the role of the change agents for each in- dicator. Based on these results, it can be said that the unfreeze dimension is proven.

Figure 3 shows that the move dimensions consist of 26 green lines, one red line, and five blue lines. Of the five indicators, two are substantiated, namely indicator 1 and indicator 3, which are marked by a green line for all informants. There are five blue lines scattered on indicators 2, 4 and 5, which indicate that some interviewees had contradictory opinions on the three indicators. Even so, it can be concluded that indicators 2 and 4 are substantiated because there is only one participant had contradictory opinions on them. The fifth indicator can be said not to be proven because there are two blue lines and one red line. This is also supported by several statements that the fifth indicator could not be carried out comprehensively and depended on each agent of change.

As seen in Figure 4 there are 18 green lines, five red lines, and three blue lines. Of the six indicators, two are perfectly fulfilled, namely indicators 2 and 3, which are marked by a green line for all informants. In addition, there is one indicator that is not fulfilled, namely indicator 6 , which is marked by three red lines, which indicate that the three interviewees disagreed with this indicator. For the fifth indicator, there are two blue lines, which indicate that there are two contradictory sources, and one red line, which indicates that there was one source who refused this indicator. It can therefore be concluded that indicators 5 and 6 are not fulfilled.

\section{Discussion}

The agents of change at Bappenas come from within the organization, appointed as individuals representing each work unit to assist in the process of implementing bureaucracy reform. The change agents responsible for implementing the bureaucracy reform also have a 


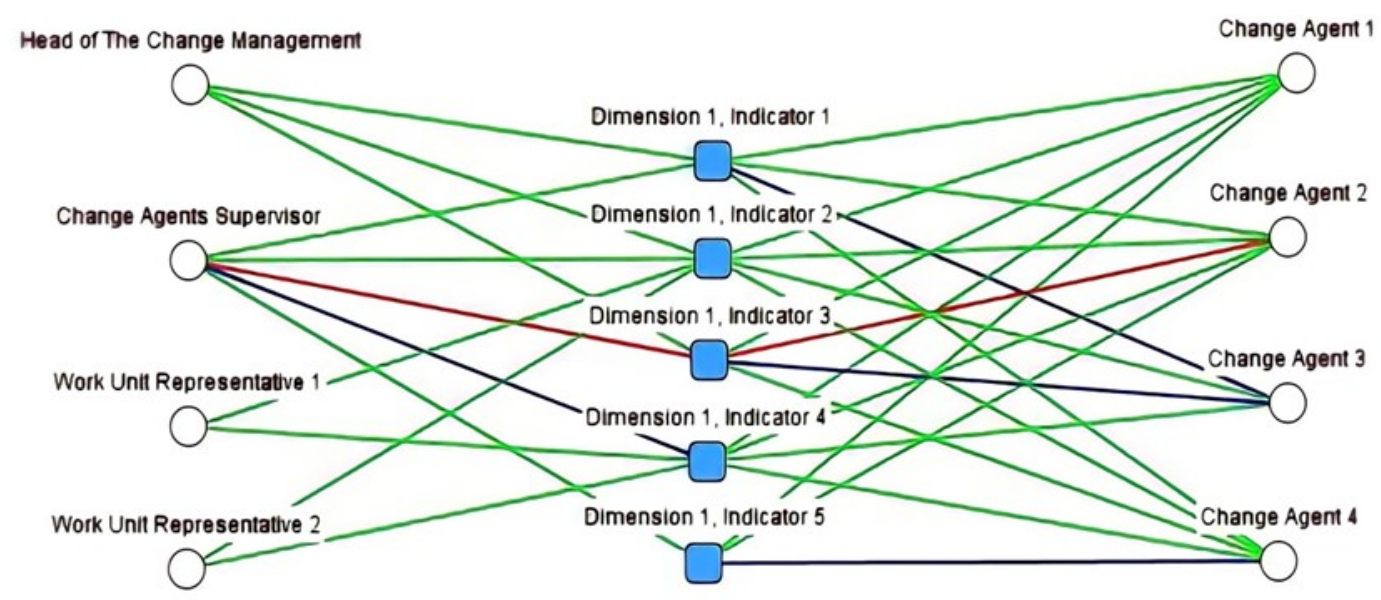

Figure 2. Unfreeze Dimensional Data Processing Results

Source: Results of the Data Processing using the Discourse Network Analyzer (2020)

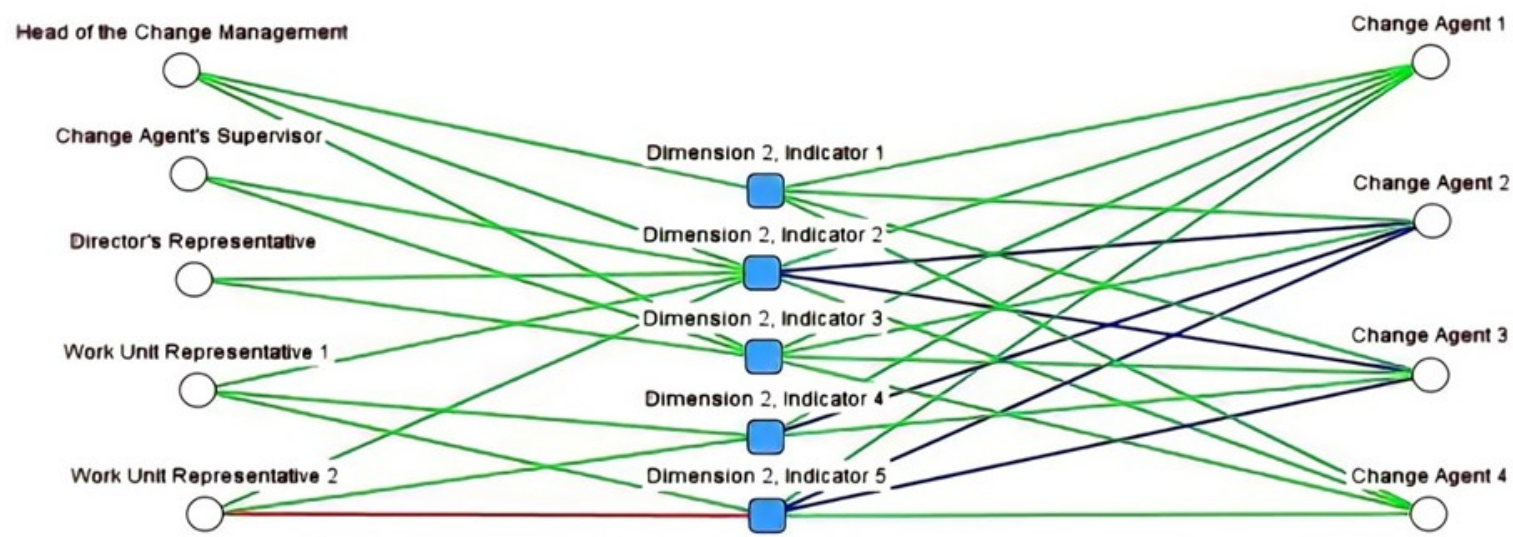

Figure 3. Results of the Move Dimension

Source: Results of the Data Processing using the Discourse Network Analyzer (2020)

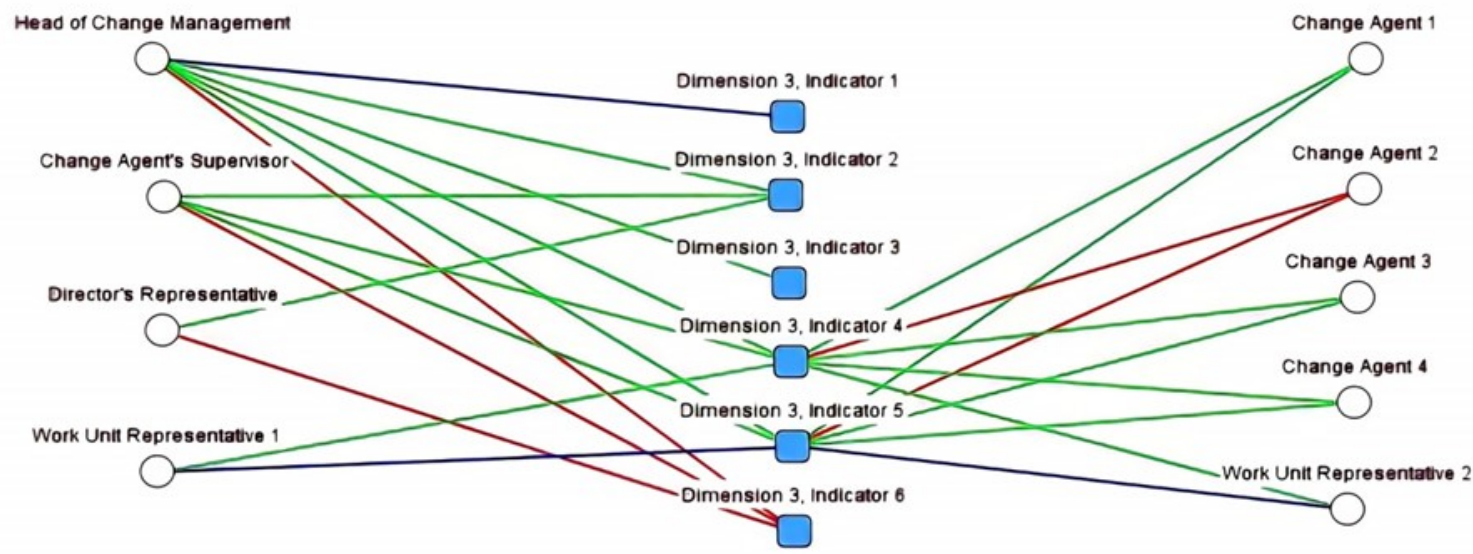

Figure 4. Results of the Freeze Dimension

Source: Results of the Data Processing using the Discourse Network Analyzer (2020) 
role in the implementation themselves. They were appointed in stages, namely at ministry level and work unit level. This study discusses their role in the stages of change management in bureaucracy reform. To help the data retrieval process, the researchers elaborated on the change management stages of Lewins' (1951) with change agent's role theory proposed by Havelock (1973). This was done in order to observe the role of change agents in the unfreeze, move and refreeze stages.

Role of Change Agents in the Unfreeze Stage

The unfreeze stage proposed by Lewins (1951) refers to the organizational conditions that are considered to be far from the goals to be achieved; therefore, at this stage preparations are made to implement the changes (Hossan, 2015). In the unfreeze stage, several roles are played by change agents, including identifying the driving factors for change, identifying and suppressing resistance, identifying particular behavior, acting as catalysts, and providing solutions.

First, change agents play a role in identifying the driving factors for change, for which they need to map the change needs in their work unit. In identifying these factors, they need to analyze the micro-environment of the organization, in this case the work unit, and think critically about the results of the change needs analysis (Cawsey et al., 2012). Identification of the driving factors for change needs to be made by the change agents because they play an important role in shaping and determining change strategies (Robbins \& Barnwell, 2006). Even though this is done in every work unit, it does not rule out the possibility of change agents conveying information on the driving factors of change to the ministry, so that the change process can be planned jointly.

The second role of change agents is illustrated by their involvement in identi- fying factors causing resistance and suppressing these. The observation process is conducted by them by taking into account the number of employees in their work units who are for and against changes and implementation of bureaucracy reform. Dewi and Kurniawan (2019) argue that change agents must be able to take advantage of resistance to make changes based on the votes/opinions of members in their work units. Other efforts made by agents of change at Bappenas to suppress resistance are by conveying rules, benefits, risks and taking approaches members of work unit.

The third role is to identify existing and expected behavior. Nevertheless, this role is unachieved because agents of change do not play a role in identifying the behavior of each member in their work unit, but rather act in a top-down manner, conveying the values set by Bappenas to their work unit. The agents of change are indirectly trying to support the formation of a new culture at Bappenas, which is in line with Gilley (2005), in that change agents attempt to form a new culture through behavior change (Gerwing, 2016). Another way that agents of change at Bappenas give examples of expected behavior is by becoming role models.

The fourth important role of change agents in driving change is as catalysts. They are known as such because they introduce and encourage change to members of their work units in line with their duty to internalise change and implement bureaucracy reform . Mitchell (2012) argues that this role is also illustrated by the actions of change agents in motivating and influencing work unit members to care about the implementation of bureaucratic change and reform. This is achieved by making agents of change champions who introduced three major changes consisting of strengthening the structure, establishing business processes, establishing Key Performance Indicators (KPI) at 
Bappenas. The methods change agents use to encourage the change process include informing people about the change plans, and reminding officials in the work unit of the short-, medium-, and long-term benefits that will be obtained from the changes implemented. Therefore, the role of the change agent as a catalyst can accelerate change (Higgins, C. A., \& Kreischer, 2004).

The fifth role played is as a solution giver to either the leader or the bureaucracy reform team. The agents of change at Bappenas are considered to be cooperative in providing useful inputs to support the change process. Their activeness in expressing their opinions must also be facilitated, in order for them to express their opinions in the change agent forum. Agents of change also tend to be active in making decisions related to factual matters and will be asked to provide opinions regarding policies that will be undertaken jointly to facilitate the working of both change agent and works unit. Hutton (1994) states that agents of change may devise an appropriate solution that can be shared through knowledge sharing, so that superiors and the bureaucracy reform team are aware of it (Klerk, 2010).

The Role of Change Agents in the Move Stage

In the process of implementing change at Bappenas, several activities were undertaken to support the changes, namely through socialisation, briefings and assistance for each work unit. The stages of the implementation comprised three changes, namely strengthening the structure of the National Development Planning Agency (Bappenas), improving business processes, and establishing Key Performance Indicators (KPIs). In the stages of implementing these changes, change agents play a significant role because they are appointed to assist the change process within government agencies. Based on the results of this study, there are several roles played by change agents at move stage, including involving organizational members, acting as parties who help the change process, providing solutions, and acting as resources linkers.

Higgins and Kreischer (2004) state that change agents need to involve members of their work units to spread information and ideas related to the implementation of change (Klerk, 2010). The role suggested by Higgins and Kreischer (2004) was included in the daily activities of change agents in involving members of their work units in implementing change management. This first role is illustrated by involving staff by socialising the change policy, making the changes, resolving problems that arise, and asking for opinions regarding changes that have been implemented. This is because every change plan submitted by the ministry is shown to members in each work unit, so they need to be involved at all times and change agents need to perform this role.

The second role that arises at this stage is the role of the change agent as an assistant to the change process (as a process helper), referred to as a facilitator. Hutton explains that change agent plays a role as a facilitator in supporting employees throughout the organization to deal with and adapt to existing changes (Gerwing, 2016). Change agents also build commitment to change; organise and assist groups to perform their functions effectively; manage change; and are responsible for sustaining change (Carter et al., 2012).

The third role is that of solution giver, as proposed by Havelock (1973), which involves providing solutions for work units (Hossan, 2015). Change agents at Bappenas are aware and active in doing this. This is evidenced by various opinions from both change agents themselves and work unit members, who state that change agents are active in assisting the work units in finding solutions to problems that occur by providing various al- 
ternative solutions. Moreover, change agents also assist work units in determining the right solutions for implementing changes in their work units.

The final role is as a resources linker to support the implementation of change, as stated by Havelock (1973), cited in (Hussain et al., 2018). However, this role is not played at Bappenas because the agents of change have no obligation to find out about the resources needed by the work unit. Some change agents at Bappenas stated that they did not search for the right resources to support change. Therefore, their role in linking resources has not been fulfilled because agents have not been acted equally. On the other hand, agents of change play a role in connecting work unit members with superiors, namely the leadership, the Renortala $\mathrm{Bu}$ reau, and the bureaucracy reform team. This is done so that the formulation of policies in the Echelon II Unit is in line with the policies set by the Echelon I Unit so that there is no difference in output.

Role of Change Agents in the Refreeze Stage

The final stage put forward by Lewins (1951) is refreezing, which aims to maintain the momentum of change after it has been implemented (Hossan, 2015). At this stage, Bappenas carries out monitoring and evaluation of the performance of change and bureaucracy reform of each work unit. The first role involves maintaining stability. This is very important for an organization, because this role is carried out to achieve better Ministry output in bureaucracy reform. In performing their role to maintain the stability of change, change agents need to exercise strategic and sustainable thinking (Stummer \& Zuchi, 2010). Their role in maintaining the stability of changes in their respective work units can be said to have been achieved, because they are active in monitoring the implementation of changes. The agents communicate regu- larly by always reminding the work unit to ensure that changes continue to run smoothly. In addition, to maintain the continuity of changes, updates are needed on them.

The second role in this stage is resources linker in determining change such as financial support, knowledge, and communicating changes to be determined by the leaderships. At this stage, change agents need to play a role in communicating the changes that have been implemented so that they can be formally determined by the leadership. This role is felt to have been lacking, because its implementation has not been made evenly by the agents of change at Bappenas. Some have been communicative in proposing that changes be formally stipulated, but others have not communicated the determination of changes in the assumption that they have been determined by the ministry. Therefore, it can be concluded that the role of change agents as resource linkers in this stage has not been fulfilled.

\section{Change Agent Attributes}

To create a change agent who is successful in implementing change, several attributes are needed. They should be individuals who demonstrate expertise in managing change and have personalities that reflect social skills (Klerk, 2010). At Bappenas there are no formally defined criteria because the selection is left directly to the head of each work unit. However, two general criteria are usually used, namely that the agents must have been involved in the preparation of the National Medium Term Development Work Plan (RPJMN) at least once, and the RKP at least five times. In addition, the results of this study found that Bappenas pays attention to matters relating to the skill attributes and behavioral attributes proposed by Weiss (2003) in selecting the agents. 


\section{Physical Ability Attribute}

The first attribute is that of physical skill, as agents needs to be able to physically undertake their duties and functions. This ability is related to how change agents take advantage of their physical condition to take part in the activities that support the change process. The findings are based on the in-depth interviews when selecting change agents at Bappenas, which do not pay attention to the physical attributes of a person. Therefore, agents of change do not need to have special physical abilities because every individual at Bappenas is deemed capable of performing their tasks and functions, and any activity that requires physical abilities. This is because the determination of change agents is based more on the skills and behavior of the individuals.

\section{Skill Attribute}

The skills attribute is considered very important by Bappenas when selecting quality change agents. Therefore, it can be said to be fulfilled because Bappenas agrees that knowledge, experience, communication skills, and the identification, diagnosis and solving of problems are qualities that must be possessed. Werner and DeSimone, (2012) argue that the skills attribute, consisting of a person's knowledge, skills and abilities, will indirectly affect the performance, behavior and actions of change agents when undertaking change (Long et al., 2014)

Two types of knowledge must be mastered, namely knowledge of bureaucracy reform and of change management. The former will help agents of change to understand the patterns and targets of implementing bureaucracy reform in government agencies. In addition, change management will provide insights for change agents to implement the improvements and changes needed to bring about bureaucracy reform. This is in line with the proposal by Morgan (1996) that change agents must have basic knowledge of change management before promoting change so that the organization is not harmed (Klerk, 2010). In addition to knowledge, another very important aspect is the experience of an individual in reducing mistakes that have been made and prior knowledge of business processes within the organization, so that it is easier to make changes.

Furthermore, change agents need to have communication skills to make it easier for them to direct members of their work units to implement changes (Stummer \& Zuchi, 2010). Agents at Bappenas are selected from individuals who are active in making suggestions and providing input, so they are familiar with the notion that the information submitted to work units should be in line with information from the ministry. This is because Gilley (2005) argues that change agents must be able to convey effective information at the right time, understand the needs of recipients, and determine different communication methods (Gerwing, 2016). To become a change agent at Bappenas, an individual needs to have skills in identifying, diagnosing and solving problems related to change. These skills are needed from the beginning to the end of the change management process because the implementation of change cannot be separated from various problems. This is because change agents need to have skills in resolving conflicts that can arise among members of a work unit that is experiencing change (Nikolaou et al., 2007). These skills are developed from the experience of individuals at Bappenas who have prepared RPJMN and RKP.

\section{Behavior Attribute}

The next attribute is the behavior attribute; change agents must display positive behavior to gain the trust of other staff. The results of the study show that to become an agent of change at Bappenas an individual must have a diligent attitude to facing change so that it can take place sustainably. Such behavior is described as an unyielding attitude and ability to keep 
Table 2. Matrix Analysis of the Roles and Attributes of Change Agent

Source: Processed Data by the Authors (2020)

\begin{tabular}{|c|c|c|}
\hline Dimensions & Indicators & Analysis \\
\hline \multirow[t]{4}{*}{ Unfreeze } & $\begin{array}{l}\text { Change agents identified the } \\
\text { driving factors for change }\end{array}$ & $\begin{array}{l}\text { Change agents identify the driving factors for change } \\
\text { from both internal and external to Bappenas }\end{array}$ \\
\hline & $\begin{array}{l}\text { Change agents identified fac- } \\
\text { tors causing resistance and } \\
\text { suppressing these }\end{array}$ & $\begin{array}{l}\text { Change agents play a role in identifying and tries to re- } \\
\text { duce the resistance that occurs by providing an under- } \\
\text { standing of the changes that will be implement. }\end{array}$ \\
\hline & Change agents as Catalyst & $\begin{array}{l}\text { Change agents carry out their duties in internalizing } \\
\text { changes to the work unit, which indirectly drives the } \\
\text { change process in the work unit. }\end{array}$ \\
\hline & $\begin{array}{l}\text { Change agents as Solution } \\
\text { Giver }\end{array}$ & $\begin{array}{l}\text { Agents of change often express opinions and solutions } \\
\text { related to the implementation of bureaucratic reform }\end{array}$ \\
\hline \multirow[t]{3}{*}{ Move } & $\begin{array}{l}\text { Change agents involved } \\
\text { members of their work units }\end{array}$ & $\begin{array}{l}\text { The way that change agents do is to involve the appa- } \\
\text { ratus in determining the appropriate method of imple- } \\
\text { menting changes }\end{array}$ \\
\hline & $\begin{array}{l}\text { Change agents as Process } \\
\text { Helper }\end{array}$ & $\begin{array}{l}\text { Change agents play a role in assisting the work unit in } \\
\text { overcoming problems that arise as a result of change. }\end{array}$ \\
\hline & $\begin{array}{l}\text { Change agent as Resource } \\
\text { Linker }\end{array}$ & $\begin{array}{l}\text { This role is not fulfilled, because change agents do not } \\
\text { carry out their duties in linking resources to support } \\
\text { change in the work unit. }\end{array}$ \\
\hline \multirow[t]{2}{*}{ Refreeze } & $\begin{array}{l}\text { Change agents involved } \\
\text { maintaining stability }\end{array}$ & $\begin{array}{l}\text { Change agents perform work units to ensure changes } \\
\text { continue to be implemented }\end{array}$ \\
\hline & Change agents as Resource & $\begin{array}{l}\text { This role is not fulfilled, because there are still agents } \\
\text { of change who have not yet approached the leadership } \\
\text { to determine changes so that their roles are not evenly } \\
\text { distributed }\end{array}$ \\
\hline \multirow[t]{2}{*}{$\begin{array}{l}\text { Physical Abil- } \\
\text { ity }\end{array}$} & $\begin{array}{l}\text { Meet the criteria of being } \\
\text { physically and mentally } \\
\text { healthy }\end{array}$ & $\begin{array}{l}\text { Bappenas does not consider physical abilities in deter- } \\
\text { mining agents of change }\end{array}$ \\
\hline & $\begin{array}{l}\text { Have the ability to carry out } \\
\text { observations }\end{array}$ & \\
\hline \multirow[t]{3}{*}{ Skills } & $\begin{array}{l}\text { Have the ability to frame } \\
\text { problems (framing skills), } \\
\text { diagnoser problems } \\
\text { (Diagnostic Participative } \\
\text { Skills), and solve problems } \\
\text { (Conflict Resolution Skills). }\end{array}$ & $\begin{array}{l}\text { This skill is considered important by Bappenas in iden- } \\
\text { tifying the source of the problem, seeing how problems } \\
\text { occur, and being useful in solving change problems so } \\
\text { that change agents can find solutions to problems that } \\
\text { occur. }\end{array}$ \\
\hline & $\begin{array}{l}\text { Have the ability to communi- } \\
\text { cate with members of the } \\
\text { organization }\end{array}$ & $\begin{array}{l}\text { Change agents need to have skills in creating effective } \\
\text { communication so that the information conveyed to } \\
\text { the work unit is in line with what is conveyed by minis- } \\
\text { try. }\end{array}$ \\
\hline & $\begin{array}{l}\text { Have knowledge about tasks } \\
\text { and carry out knowledge de- } \\
\text { velopment }\end{array}$ & $\begin{array}{l}\text { Change agents must master knowledge of change man- } \\
\text { agement and bureaucratic reform. In addition, agents } \\
\text { of change must also be able to develop the knowledge } \\
\text { they have }\end{array}$ \\
\hline
\end{tabular}


trying even if the changes that have been implemented fail or are not going well, with the change agent able to find a way out and to remedy the failure. This behavior is illustrated by the persistence of agents of change at Bappenas in trying to break the bad stigma about entrenched bureaucracy reform by always reminding people about the importance of such change and reform. Agents of change also need to have be bold in taking risks, because the implementation of change cannot be separated from various uncertainties. Furnham (2016) states that behaviors related to the courage to fail involve trying something new, experimenting and taking risks (Gerwing, 2016). The behavior of change agents with regard to taking risks is one skill that can shift the status quo in an organization, because the agents dare to act to implement change even though various risks may arise.

Gerwing (2016) states that change agents must have the creativity to find new ways to solve problems. Creativity and innovation are aspects that are considered when choosing change agents, as implementing change requires individuals to have new thoughts, methods and ideas. They are also attributes that support the tasks of agents in creating appropriate ways to make changes and to follow the characteristics of their work units so that the goals of bureaucratic change and reform can be achieved. The more agents of change are innovative and creative in their thinking, the greater the input that can be adopted by the ministry in implementing change.

In addition to some of the behaviors described by Weiss (2003), others arise from the results of this study, for example that change agents must behave humbly. Through such humility, agents can create and maintain effective relationships with other work unit members (Waddell et al., 2014). It also makes it easy for agents of change to be closer to colleagues in their work units so that there is a sense of trust and compliance to implement the changes that support bureaucracy reform.

\section{CONCLUSION}

The results of the study indicate that change agents perform several roles in supporting the implementation of bureaucracy reform management, including that catalyst, as solution provider, and as assistant to the change process. The study has also identified several other roles that arise in the management process of change in bureaucracy reform, namely that change agents play role in identifying resistance and suppressing it; in involving work unit members; in helping change organizational structures and process; in developing behaviors, values, and attitudes and in creating stability for change. The weakness of change agents is their inability to act as resources links in driving the change process. They claim driving that they have not been able to perform this role as they have not had the time to look fot effective resources due to their workload, both as change agents and in their normal job dutiesand functions. The results also show that in choosing a change agent, two attributes are considered, namely skills and behavior, as they aeea believed to affect the performance of the change agents in encouraging the implementation of change management in bureaucracy reform.

\section{ACKNOWLEDGEMENT}

The authors acknowledge and thank Department of Public Administration, Faculty of Administrative Science, Universitas Indonesia for the facility and financial support for this work.

\section{REFERENCES}

Baker, D. (2007). Strategic change management in public sector organisations. In Strategic Change Management in Public Sector Organisations. https://doi.org/10.1016/ 
Available Online at https://journal.unismuh.ac.id/index.php/otoritas

Otoritas : Jurnal Ilmu Pemerintahan, 11 (1), April 2021, 16

C2013-0-16581-6.

Carter, R., Sullivan, M., Goldsmith, D., Ulrich, D., \& Smallwood, N. (2012). The Change Champions Field Guide: Strategies and Tools for Leading Change in Your Organization. Wiley.

Cawsey, T. F., Deszca, G., \& Ingols, C. (2012). Organizational Change: An Action-Oriented Toolkit - Tupper F. Cawsey, Gene Deszca, Cynthia Ingols - Google Buku. In Sage Publications. https:// books.google.co.id/books? $\mathrm{id}=9 \mathrm{dKEi}-\mathrm{Ojc}-$ 4C\&printsec $=$ frontcover\&hl=id\&s ource $=$ gbs_ge_summary_r\&cad $=0$ $\# \mathrm{v}=$ onepage \&q\&f=false

Creswell, J. W. (2014). Research Design: Qualitative, Quantitative, and Mixed Methods Approaches (4th ed.). SAGE Publishing.

Cummings, T. G., \& Worley, C. G. (2005). Organization Development and Change (9th ed.). South-Western. https:// doi.org/10.4324/9781315232102 $-3$

Dewi, R. R., \& Kurniawan, T. (2019). Manajemen Perubahan Organisasi Publik: Mengatasi Resistensi Perubahan. Jurnal Natapraja, 7(1), 5372.

Furnham, A. (2016). Managers as change agents. Journal of Change Management, 3, 21-29. https:// doi.org/10.1080/714042525

Gerwing, C. (2016). Meaning of Change Agents within Organizational Change. Journal of Applied Leadership and Management, 4, 21-40.
Gilley, A. (2005). The Manager as Change Leader. In The Manager as Change Leader. Greenwood Publishing Group. https:// books.google.co.id/books/about/ The_Manager_as_Change_Leader.h tml? id=1vNCAy9wny8C\&redir_esc=y

Havelock, R. G., \& Havelock, M. C. (1973). Training for Change Agents. Center for Research of Utilization of Scientific Knowledge.

Higgins, C. A., \& Kreischer, D. J. (2004). Teams That Work: Thought Catalysts , Change Agents and Facilitators. Higgins Kreischer \& Associates.

www.srosenstein.com/pdf/ hkv2i1.pdf

Hossan, C. (2015). Applicability of Lewin's Change Management Theory in Australian Local Government. International Journal of Bussiness and Management, 10(6), 53-65. https://doi.org/10.5539/ ijbm.v10n6p53

Hussain, S. T., Lei, S., Akram, T., Haider, M. J., Hussain, S. H., \& Ali, M. (2018). Kurt Lewin's change model: A critical review of the role of leadership and employee involvement in organizational change. Journal of Innovation and Knowledge, 3(3), 123-127. https:// doi.org/10.1016/j.jik.2016.07.002

Hutton, D. W. (1994). The Change Agent's Handbook: A Survival Guide for Quality Improvement Champions. In ASQC Quality Press. https:// doi.org/10.1097/01445442200011000-00012

Klerk, V. der L.-D. M. (2010). The Development and Validation of a Change 
Available Online at https://journal.unismuh.ac.id/index.php/otoritas

Otoritas : Jurnal Ilmu Pemerintahan, 11 (1), April 2021, 17

Agent Identification Frameworkle [University of South Africa]. http://uir.unisa.ac.za/ handle/10500/4172

Lewin, K. (1951). Force Field Theory in Social Science. Harper \& Row.

Long, C. S., Wan Ismail, W. K., \& Amin, S. M. (2014). The role of change agent as mediator in the relationship between HR competencies and organizational performance. International Journal of Human Resource Management, 24(10), 2019-2033. https:// doi.org/10.1080/09585192.2012. 725080

Mitchell, G. (2012). Selecting the Best Theory to Implement Planned Change. Nursing Management Web Site.

Moran, J. W., \& Brightman, B. K. (2000). Leading organizational change. Journal of Workplace Learning, 12 (2), 111-119. https:// doi.org/10.1108/1366562001031 6226

Morgan, N. (1996). 9 Tips for Change Agents. Fast Company.; Fast Company. https:// www.fastcompany.com/27514/9tips-change-agents

Nikolaou, I., Gouras, A., Vakola, M., \& Bourantas, D. (2007). Selecting Change Agents: Exploring Traits and Skills in a Simulated Environment. Journal of Change Management, 7(3-4), 291-313. https:// doi.org/10.1080/1469701070177 9173

Nurtjahjo, Hendra Maturbongs, Y., \& Rachmitasari, D. I. (2013). Memahami Maladministrasi. Om- budsman Republik Indonesia.

Oliver, E. (2018). Change agency and higher education in South Africa. HTS Teologiese Studies / Theological Studies, 74(3), 1-9. doi.org/10.4102/hts.v74i3.5133

Ottaway, R. N. (1983). The Change Agent: A Taxonomy in Relation to the Change Process. Human Relations, 36(4), 361-392.

Robbins, S. P., \& Barnwell, N. (2006). Organization Theory: Concepts and Cases (5th ed.). Prentice Hall.

Rosenbaum, D., More, E., \& Steane, P. (2018). Planned organisational change management -forward to the past? An exploratory literature review. Journal of Organizational Change Management Organization Development Journal Iss Leadership \&amp Organization Development Journal, 3(6), 1-44. http:// dx.doi.org/10.1108/0953481901 0142139\%5Cnhttp://\% 5Cnhttp:// dx.doi.org/10.1108/0143773091 0981935

Saiffudin, S. (2020). Agen Perubahan Reformasi Birokrasi, Ujung Tombak Menuju Revolusi Mental. Reformasi Kita Kementerian Pendayagunaan Aparatur Negara Dan Reformasi Birokrasi. https:// kita.menpan.go.id/2020/03/26/ agen-perubahan-reformasibirokrasi-ujung-tombak-menujurevolusi-mental/

Saka, A. (2003). Internal change agents' view of the management of change problem. Journal of Organizational Change Management, 16(5), 480496. https:// doi.org/10.1108/0953481031049 
Available Online at https://journal.unismuh.ac.id/index.php/otoritas

Otoritas : Jurnal Ilmu Pemerintahan, 11 (1), April 2021, 18

4892

Stummer, M., \& Zuchi, D. (2010). Developing Roles in Change Processes - A Case Study from a Public Sector Organisation. International Journal of Project Management, 28, 384-394.

Sugiyono. (2012). Metode Penelitian Kuantitatif, Kualitatif, dan R\&D. Alfabeta.

Tupper F. Cawsey, G. D. C. I. (2016). Becoming a Master Change Agent. In Organizational Change An ActionOriented Toolkit. SAGE Publishing.

Waddell, D., Creed, A., \& Worley, C. (2014). Organizational Change: Development and Transformation (5th ed.). Cengage Learning Australia.

Weiss, A. (2003). Organizational Consult- ing: How to Be Effective Internal Change Agent. John Wiley \& Sons, Inc.

Werner, J. M., \& DeSimone, R. L. (2012). Human Resource Development. In South-Western. (6th ed., Vol. 58, Issue 3). Erin Joyner. http:// ieeexplore.ieee.org/lpdocs/ epic03/wrapper.htm? arnumber $=6071007$

Worley, C. G., \& Mohrman, S. A. (2014). Is change management obsolete? Organizational Dynamics, 43(3), 214 -224. https://doi.org/10.1016/ j.orgdyn.2014.08.008

Yusriadi, Y. (2018). Reformasi Birokrasi Indonesia: Peluang dan Hambatan. Jurnal Administrasi Publik : Public Administration Journal, 8(2), 178185. https://doi.org/10.31289/ jap.v8i2.1824 